\title{
Faktor-Faktor Yang Mempengaruhi Pengambilan Keputusan Investasi Saham
}

\author{
Nyoman Suprasta dan Nuryasman MN \\ Fakultas Ekonomi dan Bisnis, Universitas Tarumanagara \\ Email: nyomansuprastha54@gmail.com
}

\begin{abstract}
Abstrak: Pengambilan keputusan investasi adalah proses komplek yang mencakup analisis beberapa faktor dan mengikuti berbagai langkah. Tujuan dari penelitian ini adalah untuk mengidentifikasi faktor-faktor yang mempengaruhi pengambilan keputusan investasi di antara calon investor individu di Indonesia.Empat faktor perilaku dapat memengaruhi pengambilan keputusan investasi, yaitu Financial literacy, financial experience, locus of control dan experience regret Seperangkat kuesioner dibagikan kepada 420 investor saham individu untuk mengukur keputusan investasi mereka. Hasil dari penelitian ini menunjukkan bahwa financial literacy, locus of control, dan Financial Experience memiliki hubungan positip terhadap keputusan investasi mereka, sedangkan experience Regret memiliki hubungan negatip terhadap keputusan investasi mereka. Studi ini memberikan informasi yang dapat membantu untuk mengarahkan penelitian dimasa depan dan membantu merumuskan bagi pembuat kebijakan serta mendidik dalam memasukan factor-faktor yang dapat mempengaruhi keputusan para investor.
\end{abstract}

Kata kunci: Prilaku Kuangan, literasi keuangan, pengalaman keuangan, locus control, penyesalan dan keputusan investasi.

Abstrack: Investment decision making is a complex process that includes analysis of several factors and follows various steps. The purpose of this study is to identify factors that influence investment decision making among potential individual investors in Indonesia. Four behavioral factors can influence investment decision making, namely Financial literacy, financial experience, locus of control and experience regret A set of questionnaires were distributed to 420 individual stock investors to measure their investment decisions. The results of this study indicate that financial literacy, locus of control, and financial experience have a positive relationship with their investment decisions, while the Regret experience has a negative relationship with their investment decisions. This study provides information that can help guide future research and help formulate policy-makers as well as educate on the factors that can influence investors' decisions.

Keyword: Financial behavior, financial literacy, financial experience, locus control, regret and investment decisions.

\section{PENDAHULUAN}

Pengambilan keputusan keuangan telah diakui secara luas sebagai salah satu faktor penting dalam bidang keuangan dan kesejahteraan finansial. Dengan demikian, 
mengidentifikasi faktor-faktor yang secara signifikan terkait dengan keputusan keuangan merupakan salah satu masalah penting untuk dipergunakan sebagai dasar para individu untuk mengambilan keputusan keuangan.

Perilaku investasi individu berkaitan dengan pilihan tentang pembelian sejumlah kecil sekuritas untuk akunnya sendiri. Keputusan investasi seringkali didukung oleh alat keputusan. (Jagongo dan Mutswenje, 2014)

Evolusi perilaku keuangan telah membawa revolusi dalam industri keuangan. Investor sering tidak bertindak rasional dalam mengambil keputusan yang berkaitan dengan investasi. Mereka memiliki kelemahan tertentu seperti kognitif dan emosional yang mengambil peran dominan dalam mengambil keputusan investasi individu. Mereka memiliki bias perilaku dalam hal mengambil keputusan investasi.Terlepas dari semua sumber daya dan infrastruktur, investor mengadopsi beberapa jalan setelah menganalisis berbagai faktor yang dipengaruhi oleh lingkungan internal dan eksternal (Kapoor, 2016).

(Bhat, 2018) menganalisis perilaku investor Ritel di Jammu dan Kashmir terhadap berbagai alternatif Investasi. Penelitian ini didasarkan pada data primer dan sekunder. Data primer dikumpulkan dari 200 investor ritel. Salah satu temuan utama adalah bahwa investor laki-laki adalah 130 dari 200. Ditemukan bahwa pengetahuan investasi meningkatkan pengembalian dari mereka.

(Selvraj dan Nallakannu, 2018) mempelajari pola tabungan dan investasi para dosen perguruan tinggi di Distrik Terunelvi, Tamil Nadu. Penelitian ini dilakukan dengan tujuan mempelajari latar belakang sosial ekonomi, untuk mengevaluasi kebiasaan menabung para dosen. Penelitian ini didasarkan pada data primer dan sekunder. Data primer berdasarkan survei pada 60 dosen perguruan tinggi. Ditemukan bahwa para dosen sensitive tentang investasi mereka. Mereka ingin menginvestasikan uang mereka di lingkungan yang lebih aman dan mereka perlu pengembalian reguler dengan risiko lebih rendah. Hubungan yang signifikan ditemukan antara pendapatan tahunan dan tabungan tahunan.

(Ahmad, 2017) meneliti faktor-faktor yang mempengaruhi perilaku investor individu di pasar keuangan Pakistan. Penelitian ini didasarkan pada data primer melalui kuesioner dan data sekunder. Penelitian ini menghasilkan penentuan sepuluh faktor yang dianggap penting oleh lebih dari 50\% responden penelitian. Lima faktor ditemukan paling tidak mempengaruhi perilaku investor Pakistan. Penelitian ini menggunakan Cronbach alpha untuk menguji reliabilitas. Uji chi square digunakan untuk menemukan hubungan antara dua variabel. Penelitian dilakukan melalui kuesioner yang dimodifikasi pada 102 investor dan responden diukur untuk 5 kelompok dari 30 variabel.

Berbagai faktor yang memengaruhi proses pengambilan keputusan investor dan menganalisis jangkauan dan dampak informasi pada proses pengambilan keputusan investor. Sifat penelitian ini adalah deskriptif. Studi ini didasarkan pada data primer Data sekunder juga digunakan. Disimpulkan bahwa keputusan investor dipengaruhi oleh faktor psikologis dan dimensi perilaku. Dia menemukan karakteristik khas yang berbeda dari Investor India yang tinggal di Tamil Nadu dan ketergantungan investor kecil pada saran dari perusahaan terkemuka dalam membuat keputusan investasi.

(Manikan dan Muthumeenakshi, 2017) menganalisis persepsi investor terhadap pola investasi di berbagai jalan investasi. Studi ini menyimpulkan bahwa sebagian besar investor lebih suka deposito di bank dan sebagian besar investor tidak sadar menginvestasikan dananya dalam reksa dana. 
(Agarwal et al., 2017) mempelajari faktor-faktor yang mempengaruhi keputusan investor dalam berinvestasi di saham ekuitas. Data primer digunakan dalam bentuk kuesioner. Ukuran sampel adalah 100 responden Penelitian menggunakan uji-t dan skor rata-rata. Temuan dari makalah ini adalah bahwa mayoritas investor mencari dividen masa lalu dan bonus masa lalu yang dibayarkan oleh perusahaan atau mereka bertindak sesuai dengan informasi yang diberikan kepada mereka oleh pialang saham atau para ahli.

(Sowmya dan Reddy, 2016) menganalisis persepsi investor terhadap berbagai jalan investasi. Mereka sudah berusaha mengetahuinya pengetahuan dan preferensi investor untuk berinvestasi. Studi ini didasarkan pada data primer dan sekunder, yang dikumpulkan dari laporan, jurnal, situs web, Studi ini menyimpulkan bahwa mayoritas responden mengetahui semua skema tabungan. Para investor memiliki tujuan utama dari pendapatan reguler untuk investasi.

(Islamoglu et al., 2015) mempelajari bahwa ada banyak faktor yang mempengaruhi perilaku investasi yaitu demografis dan psikografis. Survei dilakukan di 277 karyawan bank di 24 cabang dari 14 bank di mana skala Likert digunakan untuk mengetahui korelasi antara investor dan banyak variabel. Untuk mengetahui hasilnya mereka menggunakan alat SPSS. Menyimpulkan bahwa ada hubungan yang signifikan dan berkorelasi dantara variabel yang diteliti.

Menurut (Guiso dan Sodini, 2013), bentuk portofolio keuangan tampaknya dipengaruhi oleh banyak karakteristik lain, antara lain finansial literacy, interaksi sosial, keakraban, dan kepercayaan.

Dalam tulisan ini, kami menghubungkan heterogenitas portofolio rumah tangga dengan tingkat pengetahuan keuangan mereka. Memperoleh sumber daya manusia dalam bentuk pengetahuan keuangan membantu investor mengidentifikasi aset dengan pengembalian tinggi, dan menghemat biaya transaksi. Kami berpendapat bahwa, informasi keuangan dapat diakumulasikan, dan keputusan untuk berinvestasi dengan memahami literasi keuangan memiliki manfaat yang signifikan dan daoat menghemat biaya.

Beberapa makalah yang menganalisis tentang informasi keuangan, dan keputusan tabungan dan portofolio, menggunakan model teoritis antara lain adalah (Jappelli dan Padula, 2013), dan (Lusardi et al., 2013), menunjukkan bahwa pendekatan kemanusiaan terhadap literasi keuangan memiliki implikasi penting untuk analisis kesejahteraan serta kebijakan yang dimaksudkan untuk meningkatkan tingkat pengetahuan keuangan dalam upaya untuk melakukan investasi.

Lebih lanjut, apabila dilihat dari factor lain, bahwa ketika seseorang percaya bahwa hasil yang diinginkan terjadi karena kemampuannya sendiri, ini disebut locus of control internal. Sebaliknya, jika seseorang berpikir hasil positif adalah karena faktor eksternal, seperti keberuntungan, kebetulan, nasib, dan orang lain yang kuat, maka ini disebut locus of control eksternal. Namun seorang investor pada umumnya memiliki jiwa yang kuat pada pengambilan keputusan investasi, itulah sebabnya mereka dapat berperilaku tidak rasional, sehingga emosi dan jiwa adalah faktor utama yang menyebabkan bias dalam pengambilan keputusan investasi.

Investor akan sangat termotivasi terhadap keputusan tertentu jika mereka pikir situasinya ada dalam kendali mereka sendiri. Locus of control adalah faktor perilaku penting dan dimasukkan dalam studi tentang faktor-faktor yang mempengaruhi pengambilan keputusan investasi dan dalam keputusan pembelian konsumen. (Özbek et al., 2013). Pengambilan keputusan konsumen mirip dengan pengambilan keputusan 
investasi karena investasi juga merupakan keputusan pembelian, tetapi dilihat dari aset modal (Kazemi et al., 2015);

Apabila memperhatikan tingkat pertumbuhan individu dibursa saham dapat dilihat pada Tabel 1. Dibawah yang menunjukkan pertumbuhan jumlah Single Investor Indentification (SID) Periode 2012 - 2018.

Tabel 1. Pertumbuhan Total Jumlah Single Investor Indentification (SID) Periode $2012-2018$

\begin{tabular}{l|l|l}
\hline \multicolumn{1}{c|}{ Tahun } & \multicolumn{1}{|c|}{ Jumlah SID } & \multicolumn{1}{|c}{ Persentase Pertumbuhan SID } \\
\hline 2012 & 281.256 & \\
\hline 2013 & 320.506 & $14 \%$ \\
\hline 2014 & 364.465 & $13,72 \%$ \\
\hline 2015 & 434.107 & $19,10 \%$ \\
\hline 2016 & 894.116 & $105,97 \%$ \\
\hline 2017 & 1.122 .668 & $25,56 \%$ \\
\hline 26 desember 2018 & 1.617 .367 & $44,06 \%$ \\
\hline
\end{tabular}

Sumber: KSEI (2018)

PT Kustodian Sentral Efek Indonesia (KSEI) merilis jumlah investor pada akhir bulan desember 2017 hingga 26 desember 2018, pada Tabel 1. jumlah SID pada tahun 2012 tercatat sebesar 281.256 selanjutnya pada tahun 2013 jumlah SID meningkat dengan persentase sebesar 14\% menjadi 320.506 begitu dengan tahun selanjutnya ditahun 2016 mengalami peningkatan persentase yang sangat besar yaitu sebesar $105,97 \%$ hal ini disebabkan karena meningkatnya perekenomian Indonesia di tahun tersebut, Tetapi pada tahun 2017 jumlah SID di Indonesia mengalami penurunan pertumbuhan dari tahun 2016 sebesar $105,97 \%$ menjadi $25,56 \%$. Salah satu factor penyebab dari penutunan pertumbuhan ini disebabkan karena menurunnya minat investasi di pasar modal

Dalam survey yang dilakukan oleh Otoritas Jasa Keuangan pada tahun 2013 tingkat literasi keuangan Indonesia sebesar 21,8\% yang berarti dari 100 penduduk hanya sekitar 22 orang yang termasuk well literate, dengan kondisi ini masyarakat Indonesia belum sepenuhnya mengoptimalkan uang dalam kegiatan yang produktif, Dengan kondisi seperti ini, ditengarai masyarakat Indonesia belum sepenuhnya memiliki pengetahuan yang cukup mengenai bagaimana mengoptimalkan uang untuk kegiatan yang produktif. Di samping itu, masyarakat juga belum memahami dengan baik berbagai produk dan layanan jasa keuangan yang ditawarkan oleh lembaga jasa keuangan formal dan lebih tertarik pada tawaran-tawaran investasi lain yang berpotensi merugikan mereka. (OJK, 2017).

Hal ini dapat memberikan pengalaman buruk atau perasaan menyesal dalam melakukan investasi (Experience Regret) bagi para investor yang tertipu dengan praktik invetasi ilegal tersebut. Dalam hal tersebut ada berbagai cara untuk menghindari investasi ilegal agar tidak mengulangi kesalahan yang sama dalam berinvestasi yaitu :Mencari informasi tentang produk investasi yang ditawarkan, sebelum memulai investasi, seorang investor harus mencari berbagai informasi tentang produk investasi tersebut seperti legalitas hukum, sejarah berdirinya perusahaan, perkembangan produk investasi dari tahun ke tahun., menjadi investor yang cerdas, sebelum memulai kegiatan investasi seorang 
investor harus menambah pengetahuan di bidang investasi agar tidak mudah tergiur oleh penawaran yang ditawarkan oleh investasi illegal.

\section{KAJIAN TEORI}

Literasi Keuangan (Literacy Financial). Banyak makalah yang telah mendokumentasikan hubungan antara literasi keuangan dan serangkaian perilaku, khususnya dengan pengambilan keputusan dalam berinvestasi.

Literasi keuangan dapat dikaitkan dengan serangkaian perilaku yang terkait dengan tabungan, kekayaan, dan pilihan portofolio. Sebagai contoh, beberapa makalah menunjukkan bahwa individu dengan angka dan literasi keuangan yang lebih besar atau tinggi, lebih mungkin untuk berpartisipasi dalam pasar keuangan dan berinvestasi dalam saham, antara lain adalah:

(Abdeldayem, 2016) mempelajari hubungan antara literasi keuangan dan keputusan investasi di Kerajaan Bahrain. Hasil penelitian menunjukkan bahwa tingkat melek finansial investor Bahrain rendah $(38,6 \%)$ dan jauh dari tingkat yang dibutuhkan. Tingkat melek finansial berdasarkan variabel demografis menemukan bahwa wanita pada umumnya kurang melek finansial daripada pria; responden usia 41-50 lebih berpengetahuan daripada semua kelompok umur lainnya, dan melek finansial sangat berkorelasi dengan pendidikan

(Bhushan dan Medury, 2013) menilai tingkat literasi keuangan individu India yang digaji dan menemukan bahwa tingkat literasi keuangan dipengaruhi oleh jenis kelamin, pendidikan, pendapatan, sifat pekerjaan dan tempat kerja sedangkan itu tidak terpengaruh oleh usia dan wilayah geografis.

(Bhushan, 2014) melakukan penelitian untuk menguji hubungan antara literasi keuangan dan perilaku investasi individu yang digaji di India. Hasil penelitian menyimpulkan bahwa tingkat melek finansial individu mempengaruhi kesadaran serta preferensi investasi individu bergaji terhadap produk. Keuangan. Hasil penelitian juga menunjukkan bahwa responden dalam kelompok melek finansial yang tinggi memiliki tingkat kesadaran yang lebih tinggi untuk semua produk keuangan kecuali untuk tabungan kantor pos. Perbedaan yang signifikan secara statistik pada tingkat kesadaran ditemukan untuk deposito tetap bank, rekening tabungan, dana simpanan publik, reksadana, investasi pasar saham dan obligasi

Di Ethiopia, (Refera et al., 2016) mengukur dan menggambarkan literasi keuangan lintas karakteristik demografi penduduk kota di Addis Ababa. Hasil penelitian mengungkapkan bahwa lebih dari setengah sampel ditemukan memiliki tingkat melek finansial yang sedang hingga tinggi, tetapi sisanya yang memiliki tingkat melek finansial yang rendah menuntut intervensi pendidikan keuangan. Hasil penelitian juga menunjukkan bahwa perbedaan keuangan yang signifikan secara statistik lintas jenis kelamin, usia, tingkat pendidikan, status pekerjaan dan ketersediaan berkelanjutan pendapatan dalam rumah tangga.

(Abdeldayem, 2016); menyimpulkan hal yang sama bahwa responden dengan literasi keuangan rendah terutama berinvestasi dalam produk keuangan tradisional dan aman dan tidak berinvestasi banyak pada produk-produk keuangan yang relatif lebih berisiko dan dapat memberikan pengembalian yang lebih tinggi. 
Kesadaran responden serta preferensi terhadap opsi investasi tradisional jauh lebih baik daripada untuk sekuritas perusahaan, reksadana, saham ekuitas dan saham preferensi. Untuk menyimpulkan, literatur di atas tentang literasi keuangan dan jalan investasi telah menunjukkan bahwa kesadaran serta preferensi terhadap opsi investasi tradisional jauh lebih baik daripada untuk sekuritas perusahaan, reksadana, saham ekuitas dan saham preferensi.

Dapat juga dikatakan bahwa sangat sedikit penelitian yang menilai hubungan antara literasi keuangan dan preferensi investasi individu.

(Agarwal et al., 2017) menilai untuk meningkatkan literasi keuangan akan berguna untuk merencakan masa depan Studi ini mengungkapkan bahwa literasi keuangan orang terbatas dengan menghasilkan, pengeluaran, dan penghematan kelebihan pendapatan dibandingkan pengeluaran. Selain itu, literasi keuangan orang berkaitan dengan meminjam uang untuk kebutuhan mendesak dan sesekali melakukan investasi dalam investasi berisiko. Studi ini mengungkapkan bahwa literasi keuangan berkorelasi positip dengan keputusan investasi terutama terkait yang berhubungan dengan, perencanaan keuangan, pensiun dan perencanaan perumahan, asuransi, pajak penghasilan

Demikian juga penelitian yang dilakukan oleh (Yildirim et al., 2017) hasilnya menyatakan bahwa Literasi keuangan berkaitan dengan pendapatan, tabungan, pinjaman, dan pengeluaran uang, karena meminjam selalu dianggap sebagai pengaruh untuk meningkatkan kehidupan seseorang secara efisien.

(Calcagno dan Monticone, 2015) berpendapat bahwa literasi keuangan merupakan elemen penting dalam pengambilan keputusan finansial, dan banyak orang usia rendah memiliki keinginan untuk mendapatkan kualifikasi keuangan.

\section{H1: Finansial Literasi berhubungan positif dengan keputusan investasi}

Pengalaman finansial (experience financial). Selama periode pengambilan keputusan investasi, investor menghadapi faktor-faktor yang sangat kompleks seperti risiko, ambiguitas, dan kelebihan pilihan (Awais et al., 2016).

(Frijns et al., 2014).Dalam makalahnya, mereka menguji dampak pengalaman keuangan pada literasi keuangan, mereka memanfaatkan fitur unik dari Selandia Baru, di mana siswa domestik dapat memperoleh pinjaman tanpa bunga dan dapat berpartisipasi penuh dalam skema pensiun nasional sementara siswa internasional tidak dapat, dengan menggunakan pendekatan variabel instrumen untuk mengidentifikasi efek kausal dari pengalaman keuangan pada literasi keuangan dan dengan melakukan survei pada sampel dari 338 siswa bisnis dan menemukan bahwa ada efek positif dan kausal dari pengalaman keuangan pada literasi keuangan.

Sebagai hasil toleransi risiko dan pengalaman dengan investasi memiliki korelasi yang signifikan, di mana pengalaman investasi yang lebih tinggi itu mengarahkan investor menuju toleransi risiko tinggi. Atas dasar analisis empiris di atas kita dapat merumuskan hipotesis berikut.

\section{H2: Pengalaman investasi berhubungan positif dengan keputusan investasi.}

Locus of contro. Dalam bidang ekonomi, locus of control adalah salah satu keterampilan non-kognitif yang paling sering dipelajari. Sifat ini menangkap sejauh mana individu 
menganggap keberhasilan atau kegagalan dalam hidup ditentukan oleh dirinya sendiri (internal locus of control) Banyak penelitian telah menyelidiki hubungan antara locus of control dan berbagai perilaku ekonomi. Ada bukti bahwa individu dengan locus of control internal yang lebih kuat cenderung untuk: menyimpan atau berinvestasi lebih banyak (Cobb-Clark et al., 2016), memiliki gaya hidup yang lebih sehat (CobbClark et al., 2014), lebih mudah mengadopsi teknologi (Abay et al., 2017), memiliki penghasilan lebih tinggi (Piatek dan Pinger, 2016; Schnitzlein dan Stephani, 2016),

Disamping itu Locus of control telah dideskripsikan sebagai sumber daya koping yang memfasilitasi gaya koping tertentu (Van den Brande et al., 2016). Dimana mereka berpendapat bahwa locus of control merupakan penyebab hasil pada orang lain (yaitu, locus of control eksternal) yang dikaitkan dengan penghindaran, stres yang lebih besar dan kesehatan yang buruk. Disi lain Locus of control internal, telah dikaitkan dengan pencarian bantuan dan pemikiran positif, serta tingkat stres kerja yang lebih rendah secara umum.

Meskipun peran moderat dari locus of control dalam hubungan antara intimidasi di tempat kerja dan tekanan psikologis telah menerima sedikit perhatian sejauh ini, namun pada hakekatnya hubungan antara locus of control dengan prilaku ekonomi dalam hal kebijakan untuk pengambilan keputusan secara teoritis dapat dijelaskan oleh kerangka kerja teori konservasi sumber daya.

Dengan demikian dapat dikatakan bahwa individu berusaha untuk membangun dan mempertahankan sumber daya yang berharga dalam kehidupan mereka, termasuk objek, kondisi, energi, dan karakteristik pribadi. Oleh karena itu, stres dianggap sebagai reaksi terhadap situasi yang mengancam dengan hilangnya sumber daya, mengakibatkan hilangnya sumber daya aktual, atau kurangnya keuntungan yang diharapkan dalam sumber daya yang pada akhirnya hilangnya kesempatan untuk berinvestasi.

\section{H3: Locus of control berhubungan positip dengan keputusan investasi.}

Experience Regret. Penyesalan adalah salah satu emosi yang paling umum, tetapi para peneliti umumnya mengukurnya secara ad-hoc dan tidak divalidasi.

Penyesalan membentuk banyak aspek dari proses pengambilan keputusan, dari penghindaran keputusan hingga pengalihan tanggung jawab atas keputusan ke pembingkaian alternatif keputusan dan memotivasi pencarian informasi tentang alternatif keputusan dan memotivasi switching pilihan (Marcatto et al., 2015). Namun, emosi yang kompleks ini tampaknya memiliki paradoksal konsekuensi dapat membantu memandu pikiran dan perilaku tetapi juga dapat menyebabkan pengambilan keputusan

Penyesalan memainkan peran yang kompleks dan bahkan kontradiktif dalam pengambilan keputusan dan perilaku strategis. Kadang-kadang, penyesalan tampaknya merusak proses-proses pengambilan keputusan.

Kekhawatiran yang berlebihan dengan pengalaman penyesalan di masa lalu atau kemungkinan di masa depan akan mengalami penyesalan dapat menghasilkan pengambilan keputusan yang kurang optimal.

Pengalaman penyesalan mendorong pengambilan keputusan yang bijaksana dan menyeluruh untuk perilaku tentang masa depan Orang lebih cenderung mengenali dan memperbaiki keputusan buruk dari masa lalu setelah mengalami penyesalan, pengalaman 
penyesalan yang berkelanjutan tergantung pada kesempatan untuk keputusan terkait di masa depan (Buchanan et al., 2016)

(O'Connor et al., 2014) menyelidiki perkembangan penyesalan pada anak-anak, dan menemukan bahwa ketika anak-anak mulai mengalami penyesalan (antara usia 5 dan 7 tahun), kualitas pengambilan keputusan berikutnya meningkat. Perkembangan penyesalan memungkinkan anak-anak untuk belajar dari pilihan mereka sebelumnya dan dengan demikian membuat pilihan yang lebih baik ketika dihadapkan pada situasi yang sama lagi, suatu perilaku yang oleh penulis telah disebut peralihan pilihan adaptif.

(O'Connor et al., 2014) studi tentang penyesalan pada anak-anak memberikan bukti untuk mekanisme efek langsung: Para penulis menemukan pilihan perilaku switching pada anak-anak yang telah mengembangkan kemampuan untuk mengalami penyesalan, tetapi masih tidak mampu mengantisipasi hal itu, dengan demikian menunjukkan bahwa penyesalan yang berpengalaman dapat memengaruhi pilihan masa depan terlepas dari penyesalan yang diantisipasi.

Berdasarkan pendapat-pendapat diatas, maka hipotes selanjutnya dari penenlitian ini adalah sebagai berikut:

\section{H4: Experience Regret berhubungan negatip dengan keputusan investasi.}

\section{METODOLOGI}

Penelitian ini mengikuti metodologi penelitian survei. Berdasarkan penelitian sebelumnya di bidang terkait, kuesioner dibangun untuk mengukur pola investasi individu berdasarkan Usia dan Jenis Kelamin. Setelah uji coba, kuesioner diberikan kepada sekelompok orang yang usianya lebih dari 22 tahun. Di sini kami menggunakan usia minimum 22 tahun karena kami mempertimbangkan bahwa seseorang mulai mendapatkan penghasilan setelah usia ini. Data dianalisis menggunakan teknik standar analisis faktor, analisis Regresi dan teknik dasar lainnya. Sisa dari bagian ini memberikan uraian singkat tentang sampel, instrumen survei, dan prosedur survei.

Sampel responden dipilih dengan menggunakan metode non probability sampling, responden di pilih berdasarkan kriteria dan secara kebetulan penyebaran kuisoner dilakukan dengan cara menyebarkan di suatu grup atau komunitas para investor, dari teman lainnya. kriteria responden adalah investor / pelaku produk di pasar modal (saham, obligasi, reksadana dll, Asuransi produk non bpjs, investor forex (Forex Exchange - Mata uang Asing), Perserta dana Pensiun Mandiri, dan Sudah satu tahun menjadi peserta pada produk di atas.

Metode analisis dalam penelitian ini menggunakan program aplikasi Partial Least Squares (PLS) yang merupakan metode analisis data yang meniadakan asumsi-asumsi Ordinary Least Square (OLS) regresi yang mengatakan bahwa data harus terdistribusi normal secara multivariate dan tidak ada masalah multikolonieritas antar variable.

Sampel. Kelompok sasaran yang dipilih untuk penelitian ini adalah investor, yang secara teratur berinvestasi. Mereka akan berinvestasi dalam jumlah yang lebih sedikit tetapi berinvestasi secara teratur sesuai dengan penghasilan mereka. Kelompok sasaran termasuk berbagai jenis Investor seperti berdasarkan daerah apakah mereka milik daerah pedesaan atau perkotaan. 
Sampel yang digunakan dalam penelitian ini berjumlah empat ratus dua puluh investor aktif di Indonesia. Adapun ciri-ciri responden dalam penelitian ini meliputi: domilisi, umur, jenis kelamin, pekerjaan, pendapatan, status perkawinan, pendidikan terakhir, lama telah menjadi investor, tujuan investasi, informasi awal menjadi investor.

Data diperoleh dengan cara menyebarkan kuisioner. Kuisioner dibuat dengan menggunakan google form dan Kuisioner di sebarkan dengan media online yaitu dengan menggunakan aplikasi whatsapp, telegram dan line messenger, data yang diisi oleh responden melalui media online otomatis masuk ke tabulasi data sehingga kesalahan tabulasi 100 persen dapat dihilangkan. Data yang di kumpul diolah dengan menggunakan software statistik yaitu smartpls versi 3.0 pro.

Keandalan dan validitas. Untuk memastikan validitas terkait konten dari item, sesuai konteks penelitian kami tentang instrumen yang disesuaikan yang disusun, metode kami telah ditinjau dan didiskusikan dengan pakar akademis. Untuk memastikan bahwa bahasa kuesioner itu jelas untuk para investor, instrumen tersebut ditinjau oleh seorang pialang, seorang bankir investasi, dan seorang ahli dalam bahasa Inggris, bersama dengan tiga investor. Pendapat dan saran mereka dimasukkan sejauh mungkin tanpa mempengaruhi sifat pertanyaan.

Untuk menguji validitas konstruk, analisis faktor penjelas dan konfirmasi digunakan. Validitas instrumen yang konvergen dan diskriminatif dipastikan, sesuai dengan kriteria dengan menggunakan faktor konfirmasi analisis. Hasil analisis menunjukkan bahwa semua korelasi lebih besar dari nol dan dapat dianggap konvergen valid.

Validitas diskriminan dibuat dengan menghitung berapa kali suatu item berkorelasi lebih tinggi dengan item dari faktor lain daripada dengan item dari faktornya sendiri, yang seharusnya di atas 50 persen; ini juga terpenuhi, menunjukkan instrumen kami baik konvergen dan diskriminatif valid.

Studi percontohan juga dilakukan untuk menganalisis keandalan, Reliabilitas dinilai menggunakan Cronbach's $\alpha$. Semua nilai berada jauh di atas 0,70 , memungkinkan kami untuk menyimpulkan bahwa instrumen tersebut layak untuk analisis lebih lanjut. Cronbach's $\alpha$ adalah ukuran konsistensi internal dan nilainya harus lebih besar dari 0,70 , yang dalam kasus kami juga dicapai untuk sampel keseluruhan.

Validitas kriteria instrumen yang digunakan juga dianggap memuaskan karena item dengan total korelasi di atas 0,60 (Kerlinger dan Lee, 1966).

\section{HASIL DAN PEMBAHASAN}

Financial Literacy. Variabel Financial Literacy $(F L)$ diukur dengan menggunakan skala penilaian 1-10 dengan menggunakan delapan pernyataan yang dilampirkan kedalam kuisioner online yang disebar. Hasilnya adalah pada indikator FL1, paling banyak memberikan nilai delapan sebanyak 130 tanggapan dengan persentase 31 . Pada indikator FL2 sebanyak 115 tanggapan dengan persentase 27,4 persen yang memberikan nilai delapan. Pada indikator FL3 sebanyak 105 tanggapan dengan persentase 25 persen yang memberikan nilai delapan. Untuk indikator FL4 sebanyak 121 tanggapan dengan persentase $28,8 \%$ yang memberikan nilai delapan. Pada indikator FL5 responden memberikan nilai delapan sebanyak 115 tanggapan dengan persentase 27,4\%. Pada indikator FL6 sebanyak 109 responden dengan persentase $26 \%$ yang memberikan nilai 
tujuh. Pada indikator FL7 sebanyak 122 tanggapan dengan persentase 29 persen memberikan nilai delapan. Untuk indikator FL8 sebanyak 111 tanggapan dengan persentase 26,4 persen memberikan nilai delapan.

Locus of Control. Variabel Locus Of Control (LOC) diukur dengan menggunakan skala penilaian 1-10 dengan menggunakan sembilan pernyataan. Hasil pengukurannya adalah jawaban responden untuk pemberian bobot nilai pada indikator LOC1, pada indikator ini responden yang banyak memberikan nilai sembilan sebanyak 119 tanggapan dengan persentase 28,3 persen sedangkan paling sedikit memberi nilai satu,dua, dan tiga sebanyak 3 tanggapan dengan persentase 0,7 persen.

Pada indikator LOC2 paling banyak memberi nilai delapan sebanyak 130 tanggapan dengan persentase 31 persen sedangkan paling sedikit yang memberikan nilai satu, dua, dan tiga.

Pada indikator LOC3 pemberian nilai delapan sebanyak 103 tanggapan dengan persentase 24,5 persen lebih besar dibandingkan dengan yang memberi nilai satu, dua, tiga, empat, lima, enam, tujuh, delapan, dan sepuluh.

Untuk indikator LOC4 reponden paling banyak memberikan nilai delapan sebanyak 111 tanggapan dengan persentase 26,4 persen dibandingkan reponden yang memberikan nilai satu, dua, tiga, empat, lima, enam, tujuh, delapan, dan sepuluh.

Pada indikator LOC5 responden memberikan nilai delapan dengan persentase 26,7 persen lebih banyak dibandingkan dengan responden yang memberi nilai satu, dua, tiga, empat, lima, enam, tujuh, sembilan, dan sepuluh. Pada indikator LOC6 responden memberikan nilai tujuh sebanyak 114 tanggapan dengan persentase 27,1\% lebih banyak dari responden yang memberikan nilai satu, dua, tiga, empat, lima, enam, delapan, sembilan, dan sepuluh. Responden memberikan nilai delapan pada indikator LOC7 sebanyak 110 tanggapan dengan persentase 26,2\% lebih banyak dibandingkan responden yang memberikan nilai satu, dua, tiga, empat, lima, enam, tujuh, sembilan, dan sepuluh.

Pada indikator LOC8 responden memberikan bobot nilai tujuh sebanyak 112 tanggapan dengan persentase $26,7 \%$ lebih banyak dari responden yang memberikan nilai satu, dua, tiga, empat, lima, enam, delapan, sembilan dan sepuluh. Responden memberikan nilai delapan pada indikator LOC9 sebanyak 128 tanggapan dengan persentase 30,2 persen lebih banyak dari responden yang memberikan nilai satu,dua,tiga, empat, lima, enam, tujuh, sembilan, sepuluh.

Experience Regret. Variabel Experience regret (ER) diukur dengan menggunakan skala penilaian 1-10 dengan menggunakan empat pernyataan Hasil pengukurannya adalah sebagai berikut pemberian nilai pada indikator ER1, pada indikator ini responden memberi nilai dua dan enam sebanyak 59 tanggapan dengan persentase 14 persen lebih banyak dari responden yang memberikan nilai satu, tiga, empat, lima, tujuh, delapan, Sembilan, dan sepuluh.

Pada indikator ER2 menunjukkan responden memberikan nilai tiga sebanyak 64 tanggapan dengan persentase 15,2 persen lebih banyak dari responden yang memberikan nilai satu, dua, empat, lima, enam, tujuh, delapan, Sembilan, sepuluh.

Pada indikator ER3 menunjukkan responden memberikan nilai empat sebanyak 65 tanggapan dengan persentase 15,5 persen lebih banyak dari reponden yang memberi nilai satu, dua, tiga, lima, enam, tujuh, delapan, Sembilan, sepuluh. 
Pada indikator ER4 menunjukkan bahwa responden yang memberikan nilai empat sebanyak 65 tanggapan dengan persentase 15,5 lebih banyak dari responden yang memberikan penilaian satu, dua, tiga, lima, enam, tujuh, delapan, Sembilan, sepuluh.

Financial Experience. Indikator Financial Experience (FE) diukur dengan menggunakan skala penilaian 1-10 dengan menggunakan empat pernyataan. Hasil pengukuran adalah sebagai beriktut, pada indikator FE1 menunjukkan responden memberikan nilai delapan sebanyak 127 responden dengan persentase 14,8\% lebih banyak dibandingkan responden yang memberikan nilai satu, dua, tiga, empat, lima, enam, tujuh, Sembilan, dan sepuluh. Pada indikator FE2 responden memberikan nilai delapan sebanyak 104 responden dengan persentase 24,8 persen lebih banyak dibandingkan dengan responden yang memberikan nilai satu, dua, tiga, empat, lima, enam, tujuh, Sembilan, sepuluh. Untuk indikator FE3 responden memberikan nilai delapan sebanyak 116 orang dengan persentase 27,6 persen lebih banyak dibandingkan dengan responden yang memberikan nilai satu, dua, tiga, empat, lima, enam, tujuh, Sembilan, dan sepuluh. Pada indikator FE4 responden memberikan nilai delapan sebanyak 107 orang dengan persentase 25,5 persen lebih banyak dibandingkan dengan responden yang memberikan nilai satu, dua, tiga, empat, lima, enam, tujuh, Sembilan, dan sepuluh.

Investment Decision. Indikator Investment Decision diukur dengan menggunakan skala penilaian 1-10 dengan menggunakan enam pernyataan. Hasil pengukurannya adalah pada indikator ID1 menunjukkan responden memberikan nilai delapan sebanyak 135 orang dengan persentase 32,1 persen lebih banyak dari responden yang memberikan nilai satu, dua, tiga, empat, lima, enam, tujuh, sembilan, dan sepuluh.

Pada indikator ID2 sebanyak 104 orang memberikan nilai tujuh dengan persentase 24,8 persen lebih banyak dari responden yang memberi nilai satu, dua, tiga, empat, lima, enam, delapan, sembilan, dan sepuluh. Pada indikator ID3 responden memberikan nilai sembilan sebanyak 105 orang dengan persentase 25 persen lebih banyak dari responden yang memberikan nilai satu, dua, tiga, empat, lima, enam, tujuh, delapan, dan sepuluh. Pada indikator ID4 responden memberikan nilai tujuh dengan persentase 25,2 persen lebih banyak dari responden yang memberikan nilai satu, dua, tiga, empat, lima, enam, delapan, sembilan, dan sepuluh.

Untuk indikator ID5 responden memberi nilai tujuh sebanyak 118 orang dengan persentase 28,1 persen lebih banyak dibandingkan responden yang memberikan nilai satu, dua, tiga, empat, lima, enam, delapan, sembilan, dan sepuluh. Pada indikator ID6 responden memberi nilai tujuh sebanyak 115 orang dengan persentase $27,4 \%$ lebih banyak dari responden yang memberi nilai satu, dua, tiga, empat, lima, enam, delapan, sembilan, sepuluh.

\section{Analisa Statistik}

Model Penelitian. Analisa statistik dilakukan dengan melakukan uji outer dan uji inner model. Uji outer model untuk menguji valitditas dan reliabilitas. Uji inner model dilakukan untuk menguji hipotesis, goodness of fit, dan koefisien determinasi. Model penelitian yang dibuat disajikan pada gambar 1. Gambar 1 menyajikan bagaimana setiap variabel saling berhubungan sebagai variabel sebab dan akibat yang dibuat berdasarkan kajian teori sebelumnya. Jumlah indikator pada setiap variabel yang digunakan 
berdasarkan dekripsi tiap variabel. Analisa data menggunakan software aplikasi SmartPLS versi 3.0 pro.

Gambar 1. Model Penelitian

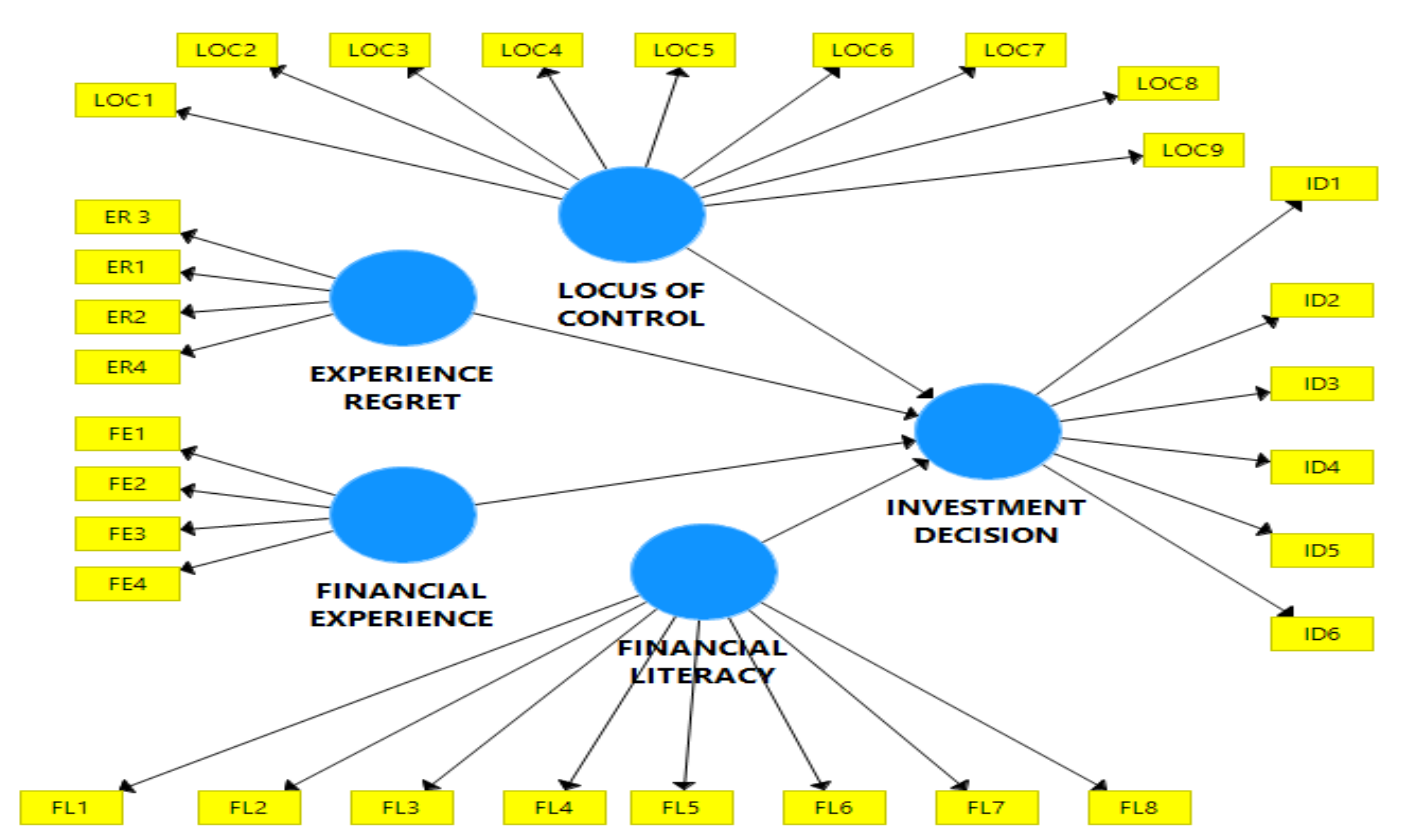

Pada gambar 1 menunjukkan variabel Financial Literacy (FL) di ukur dengan delapan indikator, Financial Experience (FE) di ukur dengan empat indikator, variabel Locus Of Control (LOC) di ukur dengan sembilan indikator, dan variabel Experience Regret diukur dengan empat indikator.

Uji Outer Model. Uji outer model dilakukan untuk menguji validitas dan reliabilitas. Uji validitas menggunakan Convergent Validity, Cross Loading. Uji reliability dilakukan dengan uji Loading Factor.

Uji Validitas. Uji validitas menggunakan Convergent Validity, Cross Loading hasil uji statistik tersebut disajikan pada gambar 4.2.

Convergent Validity. Indikator variabel dinyatakan valid apabila nilai loading factor lebih besar dari 0,6 terhadap konstruk yang dituju (Hair et al. 2011). Hasil uji loading factor disajikan pada gambar 2 . 
Gambar 2. Hasil Uji Convergent Validity

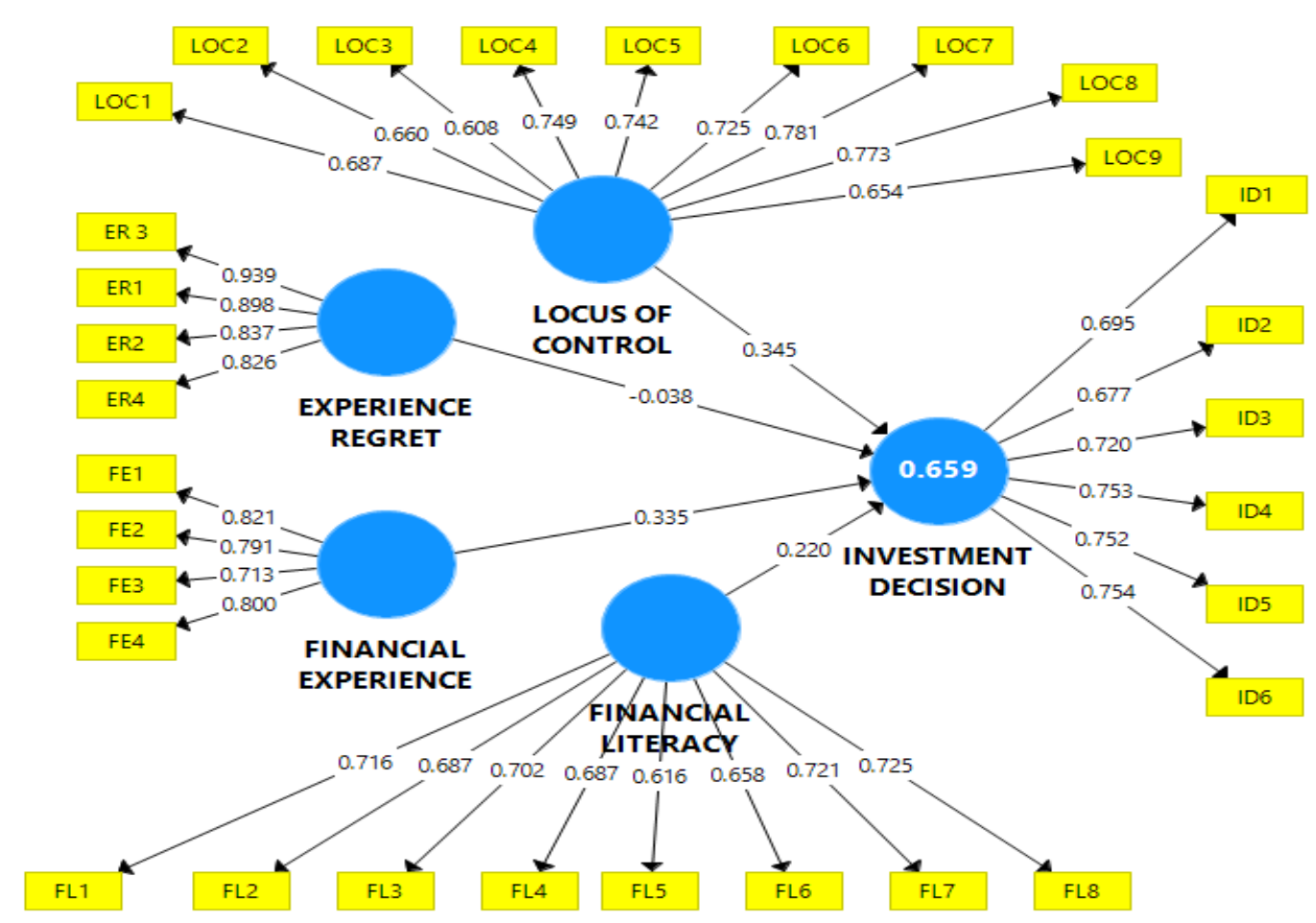

Gambar 2 menunjukkan hasil uji convergent validity denga melihat nilai loading factor. Variabel indikator dinyatakan valid jika nilai koefisien convergent validity lebih besar dari 0,6 (Hair et al. 2011). Berdasarkan kriteria yang diperoleh dimulai dari indikator Financial Literacy (FL) yaitu dari FL-1 sampai dengan FL-8, indikator Financial Experience (FE) yaitu FE-1 sampai dengan FE-4, indikator Locus Of Control (LOC) yaitu LOC-1 sampai dengan LOC-9 dan indikator Experience Regret (ER) yaitu ER-1 sampai dengan ER-4 dinyatakan valid.

Uji Validitas dengan Cross Loading. Untuk memperkuat hasil uji validitas dengan Convergent Validity, dilakukan uji validitas dengan Cross Loading. Satu inditator dari satu variable tertentu akan dinyatakan valid jika nilai cross loading dari indikator tersebut paling besar dibandingkan dengan indicator yang sama dari variable yang lain dalam satu baris (Hair et al., 2011).

Uji Reliabilitas. Pada pengujian reliabilitas ini dilakukan dengan melihat nilai cronbach's alpha atau bisa melihat nilai composite reliability. Nilai yang disarankan untuk kriteria ini $>0,7$ (Hair et al., 2011). Hasil pengujian reliabilitas ini disajikan pada tabel 1 . 
Tabel 1. Hasil Uji Reliabilitas

\begin{tabular}{l|r|r|r}
\hline & $\begin{array}{c}\text { Cronbach's } \\
\text { Alpha }\end{array}$ & \multicolumn{1}{c|}{ rho_A } & $\begin{array}{c}\text { Composite } \\
\text { Reliability }\end{array}$ \\
\hline EXPERIENCE REGRET & 0.907 & 1.167 & 0.93 \\
\hline FINANCIAL EXPERIENCE & 0.788 & 0.796 & 0.863 \\
\hline FINANCIAL LITERACY & 0.843 & 0.847 & 0.879 \\
\hline INVESTMENT DECISION & 0.82 & 0.822 & 0.87 \\
\hline LOCUS OF CONTROL & 0.876 & 0.882 & 0.901 \\
\hline
\end{tabular}

Pada tabel 1 menunjukkan nilai Cronbach's Alpha pada variabel ER (Experience Regret) adalah di atas 0,7, hal ini menunjukkan bahwa indikator ER dinyatakan reliable. Begitu pula dengan indikator FE (Financial Experience), FL (Financial Literacy), ID (Invesment Decision), dan LOC (Locus Of Control) nilai Cronbach's Alpha dan Composite Reliability diatas 0,7 .

Kontribusi Indikator Terhadap Variabel. Kontribusi dalam setiap indikator diukur dengan metode boostrapping pada software smartpls. Metode bootstrapping ini juga menjadi dasar untuk melakukan uji hipotesis melalui uji T. Hasil bootstrapping disajikan pada gambar 3.

Gambar 3. Uji Hipotesis dengan Boostrapping

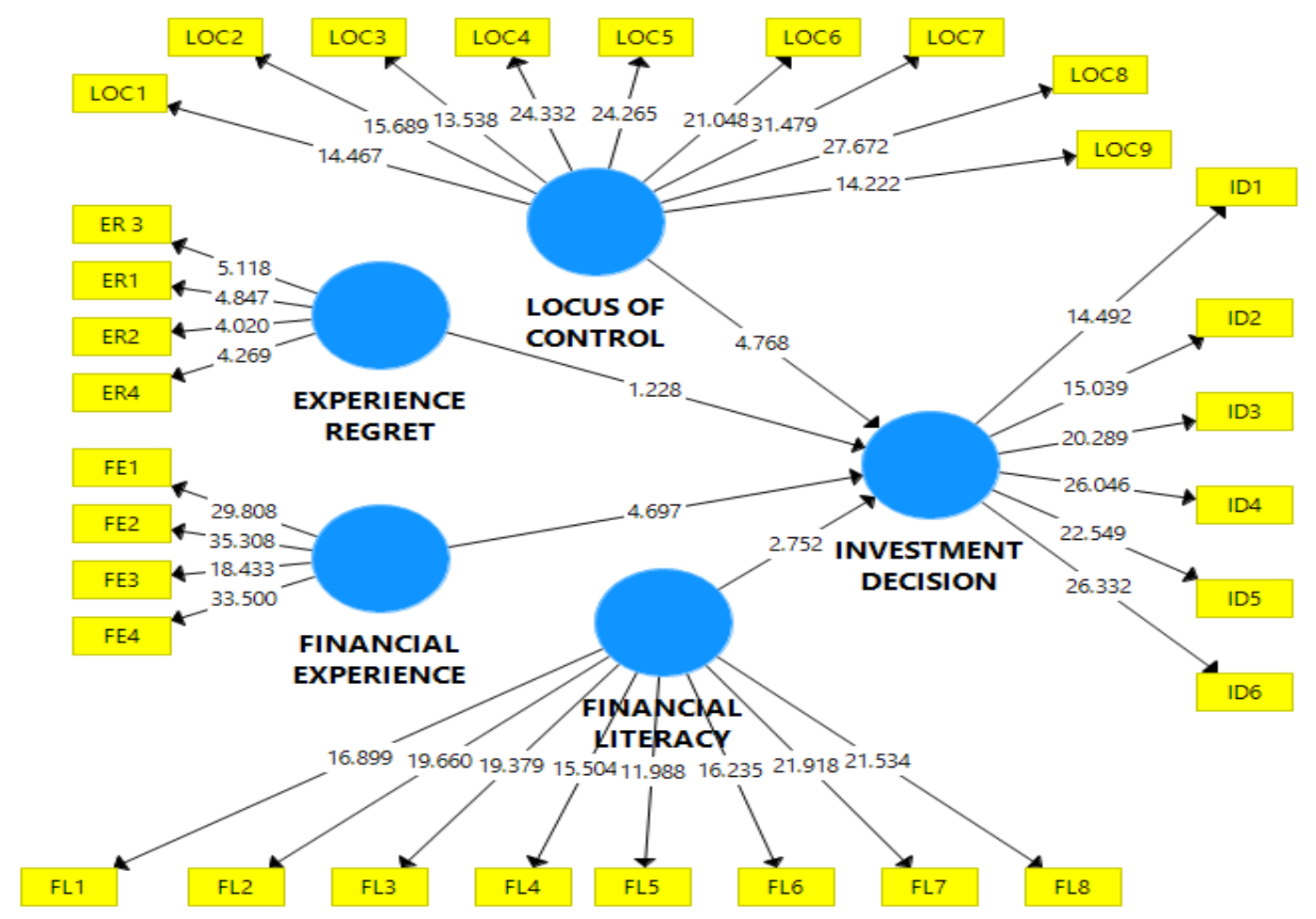

Pada gambar 3 menunjukkan nilai kontribusi pada variabel financial literacy yang paling dominan di indikator FL7 sebesar 21,918, sedangkan nilai kontribusi yang terkecil 
pada indikator FL5 sebesar 11,998. variabel financial experience pada indikator FE2 memiliki nilai kontribusi yang paling dominan sebesar 35.308 sedangkan indikator FE3 memiliki nilai kontribusi paling kecil sebesar 18,433, variabel locus of control pada indikator LOC7 memiliki nilai kontribusi yang paling dominan sebesar 31,479 sedangkan nilai kontribusi yang paling kecil pada LOC3 sebesar 13,538.

Uji Hipotesis. Pada pengujian hipotesis dilakukan dengan menguji nilai T statistik dari penelitian. Dalam uji ini kriteria untuk diterima sebuah hipotesis yang di ajukan dalam penelitian adalah nilai $\mathrm{T}$ statistik harus lebih besar sama dengan 1,96. Hasil uji hipotesis pada penelitian ini disajikan pada tabel 2

Tabel 2. Hasil Uji Hipotesis

\begin{tabular}{l|c|c|c}
\hline & Original Sample (O) & T Statistics (|O/STDEV|) & P Values \\
\hline $\mathrm{ER} \rightarrow$ ID & -0.038 & 1.254 & 0.211 \\
\hline $\mathrm{FE} \rightarrow$ ID & 0.335 & 4.687 & 0 \\
\hline $\mathrm{FL} \rightarrow$ ID & 0.22 & 2.766 & 0.006 \\
\hline $\mathrm{LOC} \rightarrow \mathrm{ID}$ & 0.345 & 5.04 & 0 \\
\hline
\end{tabular}

Hasil Uji Hipotesis. Pada tabel 2 menunjukkan nilai original sample variabel Experience regret terhadap Investment Decision sebesar -0,038, artinya variabel experience regret memiliki pengaruh negatif terhadap variabel investment decision. Pengaruh variabel experience regret terhadap investment decision tidaksignifikan dengan nilai T-statistik sebesar 1,254 dan P- value sebesar 0,211.

Variabel financial experience terhadap investment decision sebesar 0,335, artinya variabel financial experience mempunyai pengaruh positif dan signifikan terhadap variabel investment decision. Nilai T- statistic sebesar 4,687 dan P-values sebesar 0 jadi berpengaruh secara positip

Variabel financial literacy terhadap variabel investment decision sebesar 0,220, artinya variabel financial literacy mempunyai pengaruh positif dan signifikan terhadap variabel investment decision. Nilai T-statistik sebesar 2.766 dan P-value sebesar 0,006..

Variabel locus of control terhadap variabel investment decision sebesar 0,345 , artinya variabel locus of control mempunyai pengaruh positif terhadap variabel investment decision. Pengaruh variabel locus of control terhadap investment decision signifikan dengan T-statistik sebesar 5,040 dan P-values sebesar 0.

\section{DISKUSI}

Penelitian ini meneliti terhadap empat ratus dua puluh investor pasar modal di seluruh Indonesia. Hasil dari penelitian ini menunjukkan bahwa financial literacy, financial experience, dan locus of control memiliki hubungan positif terhadap investment decision sedangkan pada variabel experience regret memiliki hubungan negatif terhadap investment decision. 
Financial Literacy adalah pengetahuan tentang konsep keuangan serta kemampuan untuk membuat keputusan informasi tentang perencanaan keuangan dan manajemen keuangan. Hasil Penelitian ini menunjukkan Financial Literacy mempunyai pengaruh positif terhadap Invesment Decision, ini artinya semakin baik pengetahuan dan kemampuan seseorang dalam mengelola keuangannya maka keputusan investasi akan semakin efektif. Untuk meningkatkan efektivitas keputusan investasi maka dari sisi financial literacy perlu di dorong dengan cara memperbaiki dalam membuat perencanaan investasi Karena dalam indikator ini FL7 memberikan kontribusi yang paling dominan.

Financial Experience adalah suatu pengalaman individu yang terjadi dalam mengatur dan mengelola keuangannya sebagai pertimbangan dan perencanaan kedepannya guna untuk memenuhi kebutuhan masa depan, Hasil ini penelitian menunjukkan Financial Experience mempunyai pengaruh positif terhadap investment decision ini artinya semakin baik pengalaman keuangan individu maka semakin baik dalam menentukan keputusan investasi. Karena pada indikator FE2 memiliki nilai kontribusi yang paling dominan, sebelum menentukan keputusan investasi individu terlebih dahulu melakukan analisis investasi sebelum melakukan investasi agar dalam menentukan suatu keputusan investasi dapat secara efektif.

Locus of control adalah keyakinan seseorang tentang sejauh mana seseorang merasakan ada atau tidaknya hubungan antara usaha yang dilakukan dengan hasil yang diterima, sehingga mereka mampu mengontrol peristiwa-peristiwa yang mempengaruhi hidupnya, Hasil ini penelitian ini menunjukkan Locus Of Control mempunyai pengaruh positif terhadap Invesment decision karena pada indikator LOC7 memiliki kontribusi yang paling dominan, ini artinya semakin tinggi individu dalam mengendalikan suatu peristiwa maka individu juga dapat mengatasi permasahahan investasi.

Experience regret adalah suatu rasa penyesalan yang dialami oleh individu akibat dari peristiwa masa lalu dan akan mempengaruhi pengambilan keputusan Hasil penelitian ini menunjukkan Experience regret mempunyai pengaruh negatif terhadap investment decision karena hal ini menunjukkan bahwa perasaan menyesal tidak menjadikan investor untuk melakukan kegiatan investasi, karena adanya tipe-tipe investor dalam menghadapi resiko investasi yaitu risk seeker, risk neutral,dan risk averter.

\section{KESIMPULAN}

Berdasarkan hipotesis, uji statistik dan pembahasan, maka penelitian ini dapat disimpulkan untuk jawaban dalam rumusan penelitian sebagai berikut: (1) Financial literacy mempunyai pengaruh positif terhadap investment decision pada investor pasar modal di Indonesia. (2) Financial experience mempunyai pengaruh positif terhadap Investment Decision pada investor pasar modal di Indonesia. (3) Locus Of Control mempunyai pengaruh positif terhadap Investment Decision pada investor pasar modal di Indonesia. (4) Experience Regret mempunyai pengaruh negative terhadap Invesment Decision pada investor pasar modal di Indonesia. 
Saran. Untuk penelitian selanjutnya disarankan untuk: (1) Memperbanyak sampel penelitian. (2) Menambah variabel indenpeden yang mempengaruhi investment decision diantaranya investment experience, risk tolerance, financial planning.

\section{DAFTAR PUSTAKA}

Abay, K. A., Blalock, G., and Berhane, G. (2017). 'Locus of control and technology adoption in developing country agriculture: Evidence from Ethiopia', Journal of Economic Behavior \& Organization, vol. 143, pp. 98-115.

Abdeldayem, M.M. (2016). Is there a relationship between financial literacy and investment decisions in the Kingdom of Bahrain? Management and Administrative Science Review, 5(4), 203 - 221.

Agarwal, P., Kureel, R.C. and Yadav, S. (2017). A study on future plan for increasing financial literacy among people. Global Journal of Finance and Management, 9(1), 29-38.

Ahmad, S. (2017). Factors Influencing Individual Investors' Behavior: An Empirical Study of Pakistan Financial Markets. Journal of Business \& Financial Affairs, Vol. 6, No. 4, pp.1-8.

Awais, M., Laber, M. F., Rasheed, N., and Khursheed, A. (2016). Impact of Financial Literacy and Investment Experience on Risk Tolerance and Investment Decisions: Empirical Evidence from Pakistan. International Journal of Economics and Financial Issues, 6(1), 73-79.

Bhat, A. A. (2018). Behavior of Retail Investors of Jammu and Kashmir towards various Investment Alternatives. Business and Economics Journal, Vol.9,No.1,pp.1-4.

Bhushan, P. (2014). Relationship between Financial Literacy and Investment Behavior of Salaried Individuals. Journal of Business Management \& Social Science Research. 3(5), $82-87$.

Bhushan, P., and Medury, Y. (2013). Financial literacy and its determinants. International Journal of Engineering, Business and Enterprise Applications, 4(2), 155-160.

Calcagno, R., Monticone, C. (2015), Financial literacy and the demand for financial advice. Journal of Banking \& Finance, 50, 363-380.

Cobb-Clark, D. A., Kassenboehmer, S. C., and Schurer, S. (2014). 'Healthy habits: The connection between diet, exercise, and locus of control', Journal of Economic Behavior \& Organization, vol. 98, pp. 1-28.

Cobb-Clark, D. A., Kassenboehmer, S. C., and Sinning, M. G. (2016). 'Locus of control and savings', Journal of Banking \& Finance, vol. 73, pp. 113-130.

Frijns, B., Gilbert, A., Tourani-Rad, A. (2014), Learning by doing: The role of financial experience in financial literacy. Journal of Public Policy, 34(01), 123-154.

Guiso, Luigi and Sodini, Paolo. (2013). Household finance: an emerging field. In George M. Constantinides, Milton Harris and René M. Stulz (eds), Handbook of the Economics of Finance, Volume 2B. Amsterdam: Elsevier, North Holland.

Hair, J. F., Ringle, C. M., \& Sarstedt, M. (2011). PLS-SEM: Indeed a silver bullet. Journal of Marketing theory and Practice, 19(2), 139-152.

Islamoglu, M., Apan, M., and Ayvali, A. (2015). Determination of Factors Affecting Individual Investor Behaviours: A Study on Bankers. International Journal of Economics and Financial Issues, Vol. 5, No. 2, pp. 531-543. 
Jagongo Ambrose and Vincent S. Mutswenje (2014) A Survey of the Factors Influencing Investment Decisions: The Case of Individual Investors at the NSE International Journal of Humanities and Social Science Vol. 4 No. 4 [Special Issue - February 2014]

Jappelli, Tullio and Padula, Mario. (2013). Investment in financial literacy and saving decisions. Journal of Banking \& Finance, 37: 2779-2792.

Kapoor Kapil (2016) An Empirical Research on the Investment Behavior of Rural and Urban Investors Towards Various Investment Avenues: A Case Study of Moradabad Region TMIMT International Journal "Special Issue- 2016", ISSN 2348-988X | Available at: $\underline{w w w . t m i m t j o u r n a l . o r g}$

Kazemi, Z., Ansarirad, B. and Asl, A.H. (2015), "The effect of control locus on process of individual Investors decision-making (Tehran Stock Exchange)", Advances in Environmental Biology, Vol. 2 No. 9, pp. 1024-1029.

Lusardi, Annamaria, Michaud, Pierre-Carl and Mitchell, Olivia S. (2013). Optimal financial knowledge and wealth inequality. NBER Working Paper 18669, National Bureau of Economic Research, Inc, Cambridge, MA (USA).

Manikan, A., and Muthumeenakshi, M. (2017). Perception of Investors towards the Investment Pattern on Different Investment Avenues - A Review. Journal of Internet Banking and Commerce, Vol.22, No. S7, pp. 1-15.

Marcatto, F., Cosulich, A., and Ferrante, D. (2015). Once bitten, twice shy: Experienced regret and non-adaptive choice switching. PeerJ, 3:e1035, https://doi.org/10. 7717/peerj.1035.

O'Connor E, McCormack T, and Feeney A. (2014). Do children who experience regret make better decisions? A develpomental study of the behavioral consequences of regret. Child Development 85(5):1995-2010.

Özbek, V., Alnıaçı, Ü., Akkılıç, M.E. and Koç, F. (2013), “The moderating role of locus of control on the links between perceived ethical problem and ethical intentions of marketing managers in Turkey", Procedia - Social and Behavioral Sciences, Vol. 99 No. 1, pp. 265-273.

Piatek, R., and Pinger, P. (2016). 'Maintaining (locus of) control? Data combination for the identification and inference of factor structure models', Journal of Applied Econometrics, vol. 31(4), pp. 734-755.

Refera, M. K., Dhaliwal, N. K., Kaur, J., (2016). Financial Literacy for Developing Countries in Africa: A review of concept, significance and research opportunities. Journal of African Studies and Development, 8(1), P. 1-12.

Schnitzlein, D. D., and Stephani, J. (2016). 'Locus of control and low-wage mobility', Journal of Economic Psychology, vol. 53, pp. 164-177.

Selvaraj, M., and Nallakannu, V. M. (2018). Saving and Investment Pattern of College Teachers. International Journal of Management Studies, Vol.-V,No. 1(1),pp.13-18.

Sowmya, K., and Reddy, J. M. (2016). A Study on Investors Perception towards Investment Avenues. International Journal of Research in Finance and Marketing, Vol. 6, No. 4, pp. 141-147.

Van den Brande W., Baillien E., De Witte H., Vander Elst T., Godderis L. (2016). The role of work stressors, coping strategies and coping resources in the process of workplace bullying: a systematic review and development of a comprehensive model. Aggress. Violent Behav. 29 61-71. 10.1016/j.avb.2016.06.004 . 
Yildirim, M., Bayram, F., Oguz, A. and Gunay, G. (2017). Financial literacy level of individuals and its relationships to demographic variables. Mediterranean Journal of Social Sciences, 8(3), 19-26. 